\title{
Extraction of essential oil from - "Ricinus communis $L . "$ - higuerilla as an alternative source of insecticides by the distillation method
}

\section{Extracción de aceite esencial de -“Ricinus communis L."- higuerilla como fuente alterna de insecticidas por el método de destilación}

\author{
BALTIERRA-COSTEIRA, Gabriela $\dagger$, DE LA GARZA-DE LUNA, Jesús Roberto ${ }^{1}$, MARTÍNEZ- \\ VELA, Veronica ${ }^{1}$ and SAN MIGUEL-IZA, Sandra Maria ${ }^{2}$ \\ ${ }^{1}$ Instituto Tecnológico Superior de Monclova Carretera No. 57Los 90's C.P 25733 Monclova, Coah.Mexico. \\ ${ }^{2}$ Universidad Tecnológica de la Región Centro de Coahuila. Carretera 57Nte Km 14.5 C.P 24710, Tramo Monclova-Sabinas, \\ Monclova, Coah. Mexico.
}

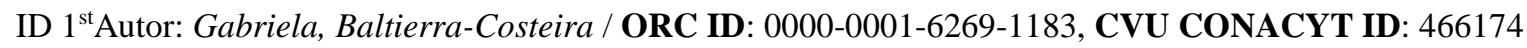 \\ ID $1^{\text {st }}$ Coautor: Jesús Roberto, De La Garza-De Luna / ORC ID: 0000-0002-6522-9514 \\ ID $2^{\text {nd }}$ Coautor: Veronica, Martínez-Vela / ORC ID: 0000-0003-0256-4865 \\ ID $3{ }^{\text {rd }}$ Coautor: Sandra María, San-Miguel Iza / ORC ID: 0000-0002-3987-2071, CVU CONACYT ID: 440841
}

DOI: $10.35429 / E J R G .2019 .9 .5 .26 .29$

Received June 10, 2019; Accepted December 08, 2019

\begin{abstract}
At present, the toxic effect of synthetic insecticides influences great importance in the development of organic alternatives derived from natural oils. Fig oil (castor) is one of the most important products worldwide, due to the many applications that include uses in medicine, cosmetics, inks, soaps, disinfectants, lubricants, varnishes and enamels. The fig tree is historically native to Africa, however it is common in Latin American countries because it is said that I arrive to this continent from the conquest, it is currently in abundance in the state of Coahuila. It has been shown that fig oil contains compounds with insecticidal activity. Therefore, the toxicity of fig oil (Ricinus communis) was evaluated based on the NOM-098-SEMARNAT-2002 standard, Environmental protection-waste incineration, operation specifications and pollutant emission limits.
\end{abstract}

Extraction, Distillation, Insecticide

\section{Resumen}

En la actualidad el efecto tóxico de los insecticidas sintéticos influye gran importancia en el desarrollo de alternativas orgánicas derivados de aceites naturales. El aceite de higuerilla (ricino) es uno de los productos de mayor importancia a nivel mundial, debido a las muchas aplicaciones que incluyen usos en medicina, cosméticos, tintas, jabones, desinfectantes, lubricantes, barnices y esmaltes. La higuerilla históricamente es originaria de África, sin embargo es común en países de América Latina pues se dice que llego a este continente a partir de la conquista, actualmente se encuentra en abundancia en el estado de Coahuila. Se ha demostrado que el aceite de higuerilla contiene compuestos con actividad insecticida. Por lo anterior se evaluó la toxicidad del aceite de higuerilla (Ricinus communis) con base en la norma NOM-098SEMARNAT-2002, Protección ambientalincineración de residuos, especificaciones de operación y límites de emisión de contaminantes.

Extracción, Destilación, Insecticida

Citation: BALTIERRA-COSTEIRA, Gabriela, DE LA GARZA-DE LUNA, Jesús Roberto, MARTÍNEZ-VELA, Veronica and SAN MIGUEL-IZA, Sandra Maria. Extraction of essential oil from - "Ricinus communis L." - higuerilla as an alternative source of insecticides by the distillation method. ECORFAN Journal-Republic of Guatemala. 2019, 5-9: 26-29

$\dagger$ Researcher contributing first author. 


\section{Introduction}

Steam distillation is one of the most used methods to extract essential oils from natural materials such as flowers, fruits and resins; The result is a $100 \%$ pure essential oil that preserves the complexity of the original smell and is much more intense than the aroma of the raw material itself. (Vasquez Ribeiro, Alva, \& Marreros Valles, 2001) One of its main functions is to act as an insecticide, which are substances widely used in the agricultural environment to control and eradicate disease vectors that improve agricultural production and protect stored products.

They are classified in several ways, either by their chemical composition, toxicological action or their method of penetration, in our research we will focus on organic since one of our main purposes is in the contribution of environmental care (Cronquist, 1981) Worldwide, the fig tree is commonly known as "fig tree of hell", "tartar", "castor", "palm of Christ", "mamoneira", "mamona", "castor vean" and "castor oil plant", among others (Falasca, Ulberich, C., \& Ulberich, E, 2012)

\section{Justification}

Nowadays synthetic insecticides are very expensive and the damage to the environment is very high. The use of alternative sources of insecticides from natural oils has generated importance. In Coahuila, the higuerilla is found in an extensive proportion which benefits for its experimental use and obtaining bioinsecticides. The main function is the use of pest control. The substances present in the oil are of the utmost importance for this investigation to avoid contamination to the environment.

\section{Problem}

In recent years the use of synthetic insecticides damages the environment due to the toxic effect of harmful substances present in their chemical composition. A natural alternative is sought for the use of insecticides in which its chemical composition has non-polluting elements.

\section{General objective}

Extraction of fig oil using steam distillation to determine its main chemical compounds.

\section{Specific objectives}

- $\quad$ Analyze the substances present in the fig tree and evaluate its environmental approach through literature.

- Evaluate if it acts as an organic insecticide

\section{Methodology}

When saturated or superheated steam is used, generated outside the main equipment, either by a boiler, a pressure cooker or a suitable flask, this technique is called "steam distillation with steam", as such. Figure 1. (Pavia, Lampmam, G. M., \& Kriz, G. S., 1988)

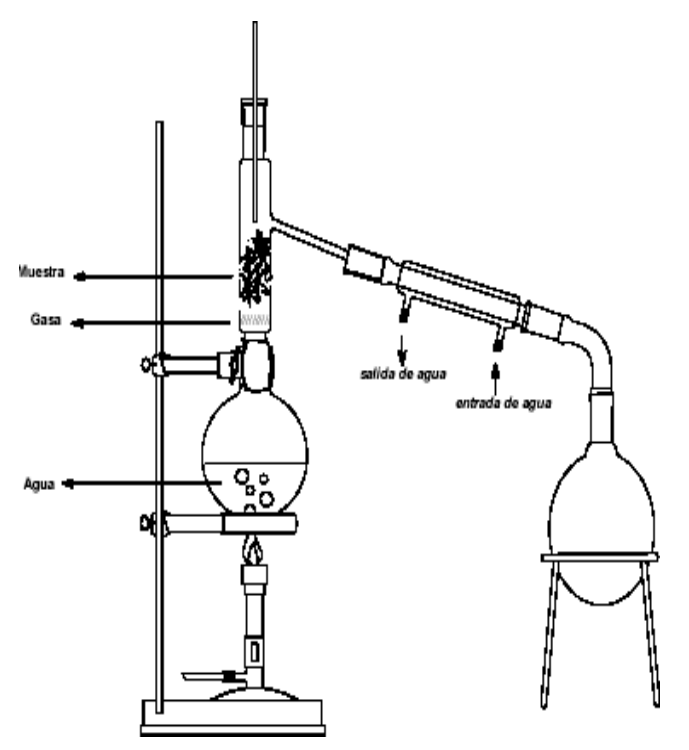

Figure 1 Steam Trailer Distiller

\section{Method and preparation}

The fig acquired from the region was used as raw material, with an average density of $0.96 \mathrm{gr} /$ $\mathrm{cm} 3$ and an average mass of $200 \mathrm{~g}$. In order to adapt the raw material for the extraction process, the following previous operations were carried out:

Cleaning: Roots and adhering soil are carefully removed and seeds that also contain oil are separated.

Washing: Its purpose is to eliminate the last traces of soil and it is carried out by means of a continuous flow of drinking water at room temperature and then it is allowed to drain and it is given an ear for six (06) hours to eliminate excess moisture. 
Cutting: Because the sample must be dried, it is recommended to cut them into $1 \mathrm{~cm}$ thick flakes to facilitate the drying operation. This was done manually with the help of stainless steel knives.

Drying: It is done to facilitate the extraction process and also achieve a longer storage time if it is not going to be extracted immediately. In this case, tests were carried out with a tray dryer at $60^{\circ} \mathrm{C}$, natural drying under the sun and natural drying under a shed. The total drying time is between one to two weeks and the final humidity of the raw material varies between 12 and $13 \%$. Grinding. An intermediate mesh hammer mill was used to obtain a greater number of particles that will make extraction more efficient by increasing the contact surface.

Figure 2 shows the flow chart of the operational process to extract the essential oil, used in this work. Extraction time varies between 18 to 20 hours.

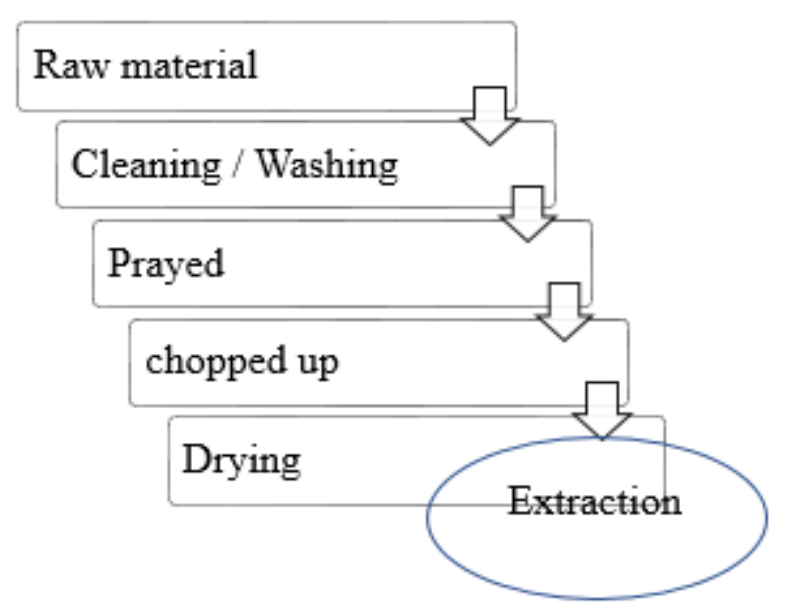

Figure 2 Flowchart for the extraction of ginger essential oil

\section{Characterization of fig oil}

The physical-chemical analyzes performed on the fig oil were: Acidity index or Total Acidity: By titration, the sample is dissolved in a mixture of toluene / ethanol, titrating with $\mathrm{NaOH}$ and using phenolphthalein as an indicator (Diaz, et al., 2009). viscosity a conventional BROOKFIELD LV, RV brand viscometer was used. The chemical analysis was performed by means of gas chromatography with a flame ionization detector (FID).

\section{Hypothesis}

Once analyzed by this method the chemical composition of oil must present organic substances which do not emit pollution to develop in the area of pesticides.

\section{Theoretical framework}

The fig tree is an oleaginous plant that is intensively cultivated, mainly to extract the oil from the seed and process it to obtain the methyl esters corresponding to the fatty acids of the oil, this is biodiesel (Simulation in Aspen of the Combustion of diesel mixtures - biodiesel, Juanuary - March, 2015) presents a growth in the form of a shrub, whose oil is used in various branches of the industry such as fertilizers, personal care, plastics, paints and about two hundred more products just to name a few; Although the origin has not been determined, it is speculated that it is native to Africa, India or China (Guerci A. \& Scarpa A., 1982) is one of the most common plants in Mexico, it has great diversity in height, color and size both of the grain as the plant with a wide adaptation, since this is distributed in $80 \%$ in the territory of the country.

In the National Institute of Forestry, Agricultural and Livestock Research (INIFAP) projects are carried out for the technification and genetic improvement of the higuerilla, with the objective of developing genotypes that offer higher oil yields and greater resistance to extreme climates such as those presented in the region (Guerci A. \& Scarpa A., 1982). Currently the effects of climate change are a constant concern for humanity for this reason the governments of countries worldwide make efforts in research and development of technology for the use of alternative energy from biomass in crops. (A. \& Domínguez S., X. A., 1990)

In general, this technique is used when the compounds meet the conditions of being volatile, immiscible in water, having low vapor pressure and high boiling point.

Essential oils are characterized by their physical properties such as density, viscosity, refractive index and optical activity. Most have a lower density than water except almond oils. (Ortuño, 2006) 


\section{Results}

\begin{tabular}{|l|r|l|r|r|}
\hline Peak & $\begin{array}{c}\text { Retention } \\
\text { time (min) }\end{array}$ & \multicolumn{1}{|c|}{ Compound } & \multicolumn{3}{|c|}{$\begin{array}{r}\text { Area } \\
\text { Area }\end{array}$} \\
\hline 1 & 7.9 & 1 ethyl, 2 methylbenzene & 0.1 & 3.4 \\
& & & 0.1 & \\
\hline 2 & 11 & Propanoic acid, 2-oxy & 0.1 & 3.4 \\
\hline 3 & 18.4 & Glycerol & 0.1 & 3.4 \\
\hline 4 & 39.5 & Hexadecanoic acid & 0.1 & 3.4 \\
\hline 5 & 43.2 & Linoleic acid & 0.1 & 3.4 \\
\hline 6 & 43.3 & $\begin{array}{l}\text { Trans-2,8-dimethyl-1,1- bis } \\
\text { (methylthio) -2-phenyl-1,2- }\end{array}$ & 0.2 & 6.8 \\
& & diidroazeto (2,1-b) & & \\
& & quinazoline r & 0.1 & 3.4 \\
\hline 7 & 43.9 & Stearic acid & 0.1 & 89 \\
\hline 8 & 47.5 & Ricinolic acid & & \\
\hline
\end{tabular}

Table 1 Chemical composition

As we can see in Table 1, ricinolic acid is the major component present in the fig seed, approximately $89 \%$, followed by Trans-2,8dimethyl-1,1-bis (methylthio) -2-phenyl- 1,2diidroazeto (2,1-b) quinazoline This compound has insecticidal and acaricidal properties (Oda, Katsurada, Shiga, Fukuchi, \& Kato, 2004).

\begin{tabular}{|l|l|}
\hline Physicochemical Parameter & Value for oil \\
\hline Acidity index & $0.5 \mathrm{mg} / \mathrm{KOH}$ \\
\hline Density & $0.86 \mathrm{gr} / \mathrm{cm}^{3}$ \\
\hline Viscosity $\left(25^{\circ} \mathrm{C}\right)$ & $9 \mathrm{~Pa} . \mathrm{s}$ \\
\hline
\end{tabular}

Table 2 Data of the physicochemical characterization of fig oil

\section{Contribution}

By means of the extraction of the oil of higuerilla it is proposed the realization of an organic insecticide avoiding the contamination of the environment thanks to its natural decomposition (Cerpa, 2007), since the oil has with great applications; As for the plant to be used, the aforementioned is chosen since it is given in abundance in the region, facilitating oil extraction tests. At the moment the chemical composition was obtained indicating that the level of toxicity is very low. On the productive level, the use of fertilizers, pesticides and insecticides has allowed increasing the productivity of the area cultivated in the world, to meet the demands of the population that grows exponentially, for this the main premise is to design new products that are useful and commercially viable but whose toxicity is minimal and that does not contribute to contamination for such a product, we will rely on NOM-098SEMARNAT-2002 Environmental protectionwaste incineration, operation specifications and pollutant emission limits whose main function is to reduce or eliminate the impact of pests on agricultural production, on the health of human beings, among others.

\section{Acknowledgments}

The authors express their sincere thanks to the Higher Technological Institute of Monclova for their support and financing for the development of this research.

\section{References}

A., D. X., \& Domínguez S., X. A. (1990). Química Orgánica Experimental. México: Limusa.Noriega.

Cerpa, M. G. (2007). Hidrodestilación de Aceites Esenciales: Modelado y Caracterización. Univ. Valladolid (UVa).

Cronquist, A. (1981). An Integrated System of Classification of Flowering Plants. The New York Botanical Garden, 1262.

Diaz, Y., Brachna, D., Hryczyñski, E., Sánchez, C., López, W., \& H. Nasif, R. (2009). Caracterización del aceite de tertaro para la obtención de biodisel. Universidad del Nordeste Argentina, 6-7.

Falasca, L., Ulberich, C., \& Ulberich, E. (2012). Developing an agroclimatic zoning model to determine potencial production areas for castor bean. 185-191.

Guerci A., \& Scarpa A. (1982). Various Uses of the Castor Oil Plant. Journal of Ethnopharmacology .

Ortuño, M. (2006). Manual practico de aceites esenciales, aromas y perfumes. España: Aiyana.

Pavia, D., Lampmam, G. M., \& Kriz, G. S. (1988). Introduction to Organic Laboratory Techniques.

Simulación en Aspen de la Combustión de mezclas diesel - biodiesel. (Juanuary - March, 2015). Ingeniería, Investigación y Tecnología, $83-92$.

Vasquez Ribeiro, O., Alva, A., \& Marreros Valles, J. (2001). Extracción y caracterizacion del aceite esencial de Jengibre. Elsevier, 707. 